\title{
OPEN
}

Published online: 14 February 2020

\section{Author Correction: A new common functional coding variant at the DDC gene change renal enzyme activity and modify renal dopamine function}

\author{
Jose Pablo Miramontes-Gonzalez, C. Makena Hightower, Kuixing Zhang, \\ Hiroki Kurosaki, Andrew J. Schork, Nilima Biswas, Sucheta Vaingankar, Manjula Mahata, \\ Michael S. Lipkowitz, Caroline M. Nievergelt $₫$, Dewleen G. Baker, Michael G. Ziegler, \\ David León-Jiménez, Rogelio González-Sarmiento, Hiroshi Ichinose \& Daniel T. O'Connor
}

Correction to: Scientific Reports https://doi.org/10.1038/s41598-019-41504-7, published online 25 March 2019

The original version of this Article contained a typographical error in the spelling of the author C. Makena Hightower, which was incorrectly given as Makena Hightower. This has now been corrected in the PDF and HTML versions of this article, and in the accompanying Supplementary Information file.

As a result, the Author Contribution section,

"J.P.M.G., M.S.L., M.G.Z., D.G.B., M.M., D.T.O. and H.I.: designed the project. J.P.M., M.H., K.Z., S.V., N.B., M.M. and A.J.S.: Performed the genetic experiments. H.K. and H.I.: performed the enzyme kinetics experiments. J.P.M.G., K.Z. and M.H. wrote the main manuscript text. J.P.M.G., D.T.O., C.M.N., D.L.-J., R.G.S. and D.G.B., reviewed the manuscript."

now reads:

“J.P.M.G., M.S.L., M.G.Z., D.G.B., M.M., D.T.O. and H.I.: designed the project. J.P.M., C.M.H., K.Z., S.V., N.B., M.M. and A.J.S.: Performed the genetic experiments. H.K. and H.I.: performed the enzyme kinetics experiments. J.P.M.G., K.Z. and C.M.H. wrote the main manuscript text. J.P.M.G., D.T.O., C.M.N., D.L.-J., R.G.S. and D.G.B., reviewed the manuscript."

(c) (i) Open Access This article is licensed under a Creative Commons Attribution 4.0 International License, which permits use, sharing, adaptation, distribution and reproduction in any medium or format, as long as you give appropriate credit to the original author(s) and the source, provide a link to the Creative Commons license, and indicate if changes were made. The images or other third party material in this article are included in the article's Creative Commons license, unless indicated otherwise in a credit line to the material. If material is not included in the article's Creative Commons license and your intended use is not permitted by statutory regulation or exceeds the permitted use, you will need to obtain permission directly from the copyright holder. To view a copy of this license, visit http://creativecommons.org/licenses/by/4.0/.

(c) The Author(s) 2020 